
POrAL L"BPAAR 


\section{Digitized by the Internet Archive in 2011 with funding from University of Toronto}





\section{CONTRIBUTIONS OF THE ROYAL ONTARIO MUSEUM OF ZOOLOGY}

No. 5: SOME ACCOUNT OF THE AMPHIBIANS AND REPTILES OF BRITISH COLUMBIA, BY E. B. S. LOGIER.

(Reprinted from Transactions of the Royal Canadian Institute, Vol. XVIII, Part 2, pp. 311 to 336) 



\title{
SOME ACCOUNT OF THE AMPHIBIANS AND REPTILES OF BRITISH COLUMBIA*
}

\author{
By E. B. S. LogIER
}

In the summer of 1928 the writer visited southern British Columbia with Professor J. R. Dymond, Mr. T. B. Kurata and Mr. C. M. Mottley. The party was engaged in a study of the trout of that region under the Biological Board of Canada, and in collecting natural history material for the Royal Ontario Museum of Zoology. Such time as was available to the writer from other duties was devoted to the search for amphibians and reptiles.

In the year 1925 a number of specimens of these groups were collected in British Columbia by Miss A. P. McDougall, a graduate student in the Department of Biology, University of Toronto, and since 1928 additional specimens have been sent to us by friends of the Museum. The collection of specimens and data of these groups from British Columbia in the Royal Ontario Museum of Zoology is still very limited, but since comparatively little collecting and study of amphibians and reptiles has been prosecuted in that province, it seemed to the writer that there was enough material at hand to make worth while the writing of an annotated list.

Twelve species of amphibians are listed by Slevin (1928) as occurring in British Columbia, and one additional species, the Western Spadefoot Toad Scaphiopus hammondii was recorded by Patch (1929, p. 138). A record of the Red Salamander Ensatina eschscholtzii published by Hardy (1926, p. C 23) seems to have been overlooked.

Eight species and subspecies of reptiles are reported by Van Denburgh (1922) as ranging into British Columbia. Records of the pigmy horned toad Phrynosoma douglassii douglassii from Osoyoos by Fannin (1898, p. 57), the desert gopher snake Pituophis catenifer deserticola from Okanagan falls and Vaseaux lake by Anderson (1914, p. G 19), and the prairie garter snake Thamnophis sirtalis parietalis from Donald, Kaslo, Nelson and Sicamous by Ruthven (1908, p. 167), are not mentioned by Van Denburgh.

The list of fourteen amphibians and fourteen reptiles presented below includes all the species and subspecies of which the writer can

\footnotetext{
*Contribution No. 5, Royal Ontario Museum of Zoology.
} 
find published reports of reliable source showing that they occur in British Columbia, or of which he has seen specimens from that province.

Amphibians

*Triturus torosus

Ambystoma decorticatum

* Ambystoma gracile

* Ambystoma macrodactylum

*Dicamptoden ensatus

* Plethodon intermedius

*Ensatina eschscholtzii

* Aneides ferreus

* Scaphiopus hammondii

* Bufo boreas boreas

* Hyla regilla

* Rana aurora aurora

Rana cantabrigensis

* Rana pretiosa pretiosa
Reptiles

Phrynosoma douglassii douglassii

* Gerrhonotus principis

* Charina bottae

* Coluber constrictor mormon

* Pituophis catenifer deserticola

* Thamnophis ordinoides ordinoides

* Thamnophis ordinoides biscutatus

*Thamnophis ordinoides elegans

* Thamnophis ordinoides vagrans

* Thamnophis sirtalis concinnus

* Thamnophis sirtalis parietalis

*Crotalus oreganus

Clemmys marmorata

*Chrysemys marginata bellii

The species marked with an asterisk (with exception of Ensatina eschscholtzii, the specimen of which met with an accident) are represented in the Royal Ontario Museum of Zoology collection and will be discussed in the succeeding pages, but a few remarks on the four species listed above but not represented in our collection will be of interest.

Ambystoma decorticalum Cope is a northern species of salamander. It is listed by Slevin (1928, p. 28) from Port Simpson where the type specimen was taken. Hardy (1928, p. E 17) records a specimen in the Provincial Museum, Victoria, which was taken at Prince Rupert. Mr. W. A. Newcombe of that Museum kindly furnished the writer with the following history of the Prince Rupert specimen, Provincial Museum No. 16: It was sent to the Museum by Mr. M. L. Bird from Prince Rupert in October, 1914. In December, 1926, it was forwarded to Mr. J. R. Slevin who identified it from the published description of the type, and in 1927 to the United States National Museum where Dr. E. R. Dunn compared it with the type specimen and confirmed Mr. Slevin's identification. Dunn (1930, p. 88) gives additional records for British Columbia from Metlakatla, Chillinae valley on Tamitly mountain, and Bella Coola. That it occurs throughout the coastal region of British Columbia there can be little doubt, since Slater (1930, p. 87) records it from the Olympic peninsula in the State of Washington.

Rana cantabrigensis Baird, Western Wood Frog, is recorded by Slevin (1928, p. 133) as having been taken at the following localities in British Columbia: Atlin, Hazelton, Kispiox valley twenty-three miles north of Hazelton, and Meadow lake twenty miles north of Clinton.

Phrynosoma douglassii douglassii (Bell), Pigmy Horned Toad, is 
reported by Fannin (1898, p. 57) from Osoyoos. It is recorded by Van Denburgh (1922, Vol. 1, p. 375) from Washington at Spokane, North Yakima and Steilacoom, so there seems to be no reason to doubt its occurrence at Osoyoos. It is the smallest and most northerly ranging species of the genus and could certainly not be confused with any other lizard occurring in British Columbia.

Clemmys marmorata (Baird and Girard), Pacific Terrapin, is reported by Van Denburgh (1922, Vol. 2, p. 976) as ranging on the Pacific slope from Lower California to British Columbia, and he states that "Lord reports it common on Vancouver island". The writer does not know of any definite locality record.

Under each species discussed in the following pages the previously published British Columbia records are listed. These are drawn from one or more of the following sources: Anderson, 1914; Cope, 1900; Fannin, 1898; Hardy, 1926, 1927, 1928; Kermode, 1913, 1927, 1929, 1930; Patch, 1922, 1929; Ruthven, 1908; Slevin, 1928; Storer, 1925; Thacker, 1924; Van Denburgh, 1922; Van Denburgh and Slevin, 1918.

All measurements are from alcoholic material and so, in the case of the snakes especially, can only be considered as approximate since there is always some shrinkage and also, since it is impossible completely to straighten the body of a preserved specimen. The length measurements given for frogs and toads were taken from the tip of the snout to the posterior surface of the ischial symphysis. In the scale formulae given for the snakes, the three counts of dorsal scales refer to the minimum number of rows near the anterior end of the body, the maximum near the centre, and the minimum near the tail, respectively. In referring to the scutes of the head, oculars, labials, etc., those on the left side are written first, i.e., preoculars $2-1$ would mean that there were two on the left side and one on the right; if written $1-2$ it would mean the reverse. If two figures are coupled by a plus sign instead of a dash, they both refer to scutes on the same side of the head, i.e., oculars $1+3$ means that there is one preocular and three postoculars on the same side of the head.

It was through the Biological Board of Canada and Dr. W. A. Clemens, Director of the Biological Station at Nanaimo, that our party was enabled to visit British Columbia. While guests at the Biological Station every possible accommodation was accorded us, including the use of the laboratories, equipment, boats, etc., and many courtesies were extended contributing much to our comfort and success. Some valuable assistance was rendered by the Canadian Pacific Railway Company. At Kaslo, the local Association of Anglers generously afforded us the use of one of their buildings as a laboratory, the use of their boats, and assisted us in other ways also. We are indebted to the Department of 
Marine and Fisheries of the Dominion of Canada for the use of the fish hatcheries at Nelson and Summerland, in which we were permitted to establish field laboratories. At Nelson, Mr. Weldon Reed, in charge of the local hatchery there, was very kind and accommodating to our party, made us feel very welcome and helped us in every way possible. While at Christina Lake Mr. H. C. Kerman permitted us to occupy his summer cottage and use his boats, and took much thought and trouble for our comfort in other ways besides. While at Summerland Mr. Geo. N. Gartrell, in charge of the hatchery, and Captain H. H. Creese were of invaluable service to our party, placing their time, their cars and their knowledge of the country and its fauna at our disposal, and favouring us with their companionship and guidance on many of our collecting trips, a number of which could not otherwise have been undertaken. Mr. G. Morgan should also be mentioned for generous assistance rendered with his time and his car, and in other ways. While at Cultus lake Dr. R. E. Foerster extended many courtesies and valuable assistance to our party, which it is indeed a pleasure to acknowledge. Too much could not be said in recognition of the contribution which these gentlemen made to the success of our work, and to our personal convenience and happiness. Throughout the summer of 1928 the writer was fortunate in having much kind co-operation from the other members of the party, i.e., Professor J. R. Dymond, Mr. T. B. Kurata and Mr. C. M. Mottley. For many of the specimens collected the writer is indebted to the following persons: Major Allan Brooks, Dr. W. A. Clemens, Captain H. H. Creese, Professor J. R. Dymond, Dr. R. E. Foerster, Mr. G. N. Gartrell, Mr. T. B. Kurata, Miss A. P. McDougall, Mr. C. M. Mottley, Mr. J. A. Munro, Mr. K. Racey, Professor G. J. Spencer and Mr. H. W. Swaine. For the loan of one of the turtles collected by Mr. E. M. Anderson in the Okanagan in 1913, and for the history of the specimen of Ambystoma decorticatum in the Provincial Museum, Victoria, the writer is indebted to Mr. W. A. Newcombe. The garter-snakes collected in 1925 and 1926 were identified by Dr. A. G. Ruthven. Certain specimens concerning which Dr. Ruthven was in doubt, owing to there being insufficient material from a region where the ranges of the forms in question came together, were later sent to Mr. J. R. Slevin who confirmed Dr. Ruthven's identifications. The garter-snakes collected in 1928 and subsequently, and also the racers, were submitted to Mr. Slevin. All of the frogs, some of the specimens of toads, and certain of the salamanders and larvae were sent to Professor T. I. Storer for examination. Some of the salamanders and salamander larvae were examined by Dr. E. R. Dunn. Our notes of scales and blotches of the bull snakes were submitted to Dr. F. N. Blanchard. To these zoologists the writer and the Royal Ontario Museum of Zoology wish to express sincere thanks for the 
identification of the specimens in question and for useful comments on diagnostic features and distribution. For information concerning certain locality names cited in the literature as being in British Columbia, for their exact locations, for subsequent changes in any of these names and for corrections of those cited in error, the writer wishes to thank Mr. J. H. Corry, Secretary of the Geographic Board of Canada; Mr. W. A. Newcombe of the Provincial Museum, Victoria; and Mr. J. R. Slevin of the California Academy of Sciences.

The scientific nomenclature used is that of Stejneger and Barbour (1923), except in the case of Ambystoma gracile.

\section{Amphibians}

Triturus torosus (Eschscholtz). PACIFIC NEwT.-Previous records from British Columbia: Bella Coola, Chilliwack river, Fraser river, Hagensborg, Hatzic, Metlakatla, and Ocean falls on the mainland; San Mateo lake near Union bay, and Victoria on Vancouver island.

Our specimens of this species are from Vancouver island near Nanaimo with the exception of one from the Fraser valley. The adult specimens in our collection range from 114 to $149 \mathrm{~mm}$. in length.

Adult specimens which are living at the Department of Biology, University of Toronto, show the following coloration: yellowish brown on dorsal surfaces, indistinctly marbled on body and tail with darker gray, and some blackish spots along margins of brown; ventral surfaces abruptly dull yellow. When these specimens were captured on August 14, 1928, shortly after transformation, they were of a deep orange-red on the now yellow region of the sides, and almost black above.

The specimen from the Fraser valley was a female of $130 \mathrm{~mm}$. in length, taken between May 1 and 15, 1925, by Miss A. P. McDougall. It was full of eggs. A specimen of $149 \mathrm{~mm}$. taken at Lone lake near Nanaimo on July 31, 1913, by Mr. T. B. Kurata had evidently finished egg laying, and the ovaries contained only minute eggs. Of two females of 114 and $115 \mathrm{~mm}$. taken at Lone lake on July 17, 1926, by Professor J. R. Dymond, one was full of ripening eggs and had evidently not yet spawned; the other had one enlarged ovary with only minute eggs.

On August 12, 1928, nineteen larvae ranging from 34 to $58.5 \mathrm{~mm}$. in length were taken at Lone lake; in five of the larger specimens the gills were beginning to disappear. On August 14, 1928, nineteen larvae were taken in a pond on Newcastle island near Nanaimo; they ranged in length from 23.5 to $46 \mathrm{~mm}$. Seventeen recently transformed newts were taken from beneath a $\log$ beside the same pond. On neither of the above dates were adults found in the water.

Patch (1922, p. 75) records specimens as having been taken in the 
water on June 10 and July 16 , and under logs beside the water on September 7. The specimen taken at Lone lake on July 31, 1913, was taken in the water where many others were also seen.

The above data would indicate that in British Columbia this species leaves the water in the middle of the summer.

Ambystoma gracile (Baird). Previous records from British Columbia: Bella Coola ${ }^{1}$, Chilliwack lake, and Hagensborg* on the mainland; Nanaimo and Victoria on Vancouver island.

There are twenty-three larvae and one transformed specimen in our collection. Ten of the larvae were taken by Miss A. P. McDougall on September 6, 1925, from ponds on Holyburn ridge near Vancouver at an altitude of 3,500 feet. They ranged in length from 52.5 to $157 \mathrm{~mm}$., and all had large gills and complete dorsal fins. Thirteen were taken in Brent's lake near Summerland by the writer on July 1, 1928. They ranged from 52 to $72.5 \mathrm{~mm}$. in length and were all completely larval. They were of a light yellow ground colour with brown mottlings which showed a vertical arrangement on the body and were scattered on the tail and fins; a yellow line practically free from mottling extended along the side of the body and tail.

The transformed specimen which measures $82.5 \mathrm{~mm}$. in length was taken by Dr. R. E. Foerster at Chilliwack on June 20, 1926.

Patch* (1922, p. 76) records the capture of larval specimens of Ambystoma paroticum (=gracile) of $44 \mathrm{~mm}$. in length at Bella Coola on June 10 , in which the "dorsal dermal border" extended to the base of the skull; and the capture of additional specimens on August 10, measuring $63 \mathrm{~mm}$., and which had lost the dermal border and gills, only the scars of the latter remaining. Patch's specimens which were transforming at $63 \mathrm{~mm}$. were from practically at sea level, while our specimens from Holyburn ridge at an altitude of 3,500 feet are still completely larval up to a length of $157 \mathrm{~mm}$.

Storer $(1925$, p. 76$)$ records a large series of specimens taken on Mount Ranier on August 14, 1911, which "contains larvae of various sizes and in various stages of transformation. The largest larva measures 160 millimeters in length; the smallest metamorphosing animal is but 108 millimeters long."

If Patch's specimens should prove to be gracile the above data would indicate the retention of larval characters in a mountain habitat to a considerably larger size.

Ambystoma gracile is listed under the name of $A$. paroticum by Stejneger and Barbour (1923, p. 6), by Storer (1925, pp. 74-76), and by

IDunn (1930, p. 88) suggests that these records of Patch's for paroticum may really refer to decorticatum. 
Slevin (1928, pp. 26-28). Dunn (1926, pp. 135, 136) published on the status of this species and showed that Siredon gracilis Baird 1857 is the larva of Ambystoma paroticum Baird 1867, so the species should be known as Ambystoma gracile (Baird).

Ambystoma macrodactylum (Baird). Long-Toed Salamander.Previous records from British Columbia: Agassiz, Bella Coola, Chilliwack lake, Clinton, Creston, Garabaldi, Hagensborg, Hatzic, East fork of Moose river, New Westminster, Stikine river at Sawmill lake, four miles north of Telegraph creek, and at Watson lake.

The Museum has received specimens of this species from Midday valley, from Okanagan Landing, and from Paul lake near Kamloops. The Midday valley specimen was taken by Miss A. P. McDougall on July 13, 1925. A portion of the tail is missing; the length from the snout to the posterior edge of the anus is $52 \mathrm{~mm}$.

The Okanagan Landing specimen was taken by Mr. J. A. Munro in 1929 and sent to us alive in June of that year. A colour sketch was made from the living specimen which later met with an accident and so was not preserved. It was about $80 \mathrm{~mm}$. in length. The ground colour was brownish black above becoming paler on the lower sides and ventrally; a broad irregularly-edged dorsal stripe from neck to base of tail, many small irregular spots on upper sides, and large irregular blotches on tail were light yellow; head extensively marked above with coalescent blotches of the same light yellow, becoming gradually black toward the snout; ventral surface with small pale spots; limbs dark, blotched with light yellow.

The Paul lake specimens are larvae. They were taken by Mr. C. M. Mottley on May 20, 1928, and measure 58.5, 59, and $67.3 \mathrm{~mm}$. respectively.

Dicamptoden ensatus (Eschscholtz). Pacific Giant SalaMANDER.-Previous records from British Columbia: Chilliwack lake, and Sumas lake.

Two larvae of 188 and $195+\mathrm{mm}$. in length were taken in Sweltzer creek near Cultus lake on August 5, 1927, by Dr. R. E. Foerster. Both of these larvae had functioning gills, and were evidently in their second summer. Storer's observations on this species indicate that metamorphosis occurs at a length of $200 \mathrm{~mm}$. or more, and that the maximum length attained in the first summer is $142 \mathrm{~mm}$., and usually not over $119 \mathrm{~mm}$. He records one specimen which attained sexual maturity as a larva. (Storer, 1925, pp. 85-87).

Plethodon intermedius Baird. Western Red-BACKed SALAMANDER.-Previous records from British Columbia: Hope on the mainland; Brentwood, Goldstream, Port Renfrew, Sooke, and Ucuelet on Vancouver island. 
Four specimens were taken by the writer from beneath forest mould and decaying leaves on the ground in thick woods close to Cultus lake on July 26,1928 . Three types of coloration were represented by these specimens - a bright red dorsal stripe, a yellow dorsal stripe, and a dark colouring in which the dorsal stripe was only faintly evident.

The colour in life of the red-striped specimen was as follows: top of head red, soiled with brown; a dark line from eye to nostril; a wide, bright red dorsal stripe from head to end of tail, bordered on each side by a black line, sharp edged above and fading out below; sides and belly brown with minute dark and whitish markings ventrally; front limbs red, faintly soiled with brown; hind limbs darkly mottled with brown on tibiae and feet, upper surfaces of thighs bright red. In the yellow striped specimen the front limbs also, and the tail are mottled with brown distally.

Ensatina eschscholtzii Gray. ReD SAlamander.-Previous records from British Columbia: Vancouver island.

One specimen was taken by the writer at Cultus lake in the same habitat as the preceding species. It was about $75 \mathrm{~mm}$. in length.

The colour in life was orange-red above and paler beneath. The upper sides were faintly greenish, the greenish hue ending abruptly above along the dorso-lateral region outlining a broad, faint dorsal stripe extending from neck on to basal half of tail; tail paler distally; limbs pale orange, hands and feet pale grayish.

The specimen died shortly after it was brought to Toronto but the fact was not discovered until some days later when it was too badly decayed to preserve. A colour sketch had been made from the living specimen.

Aneides ferreus Cope. Clouded Salamander; Rusty SalaMANDER.-Previous records from British Columbia: Mount Douglas, Mount Finlayson, Sooke, Sydney, and Union bay on Vancouver island; and Denman island.

Three specimens were taken near Nanaimo on August 1, 1928, by Mr. T. B. Kurata and the writer. They were all found in rather dry, partly decayed logs lying on the ground in a situation exposed to the sun for some hours each day. Two of them were found in the same log which was infested by a large termite colony.

The preserved specimen in our collection measures $102 \mathrm{~mm}$. in length. The colour in life was greenish gray above, marbled with rather dark rusty brown; a median dark area on top of head between orbits narrowing as it passes backward toward neck; snout pale with a dark stripe on each side from eye to nostril; skin above orbits brilliant green; lavender gray ventrally with small whitish spots. 
Hardy (1926, p. C 23), and Storer (1925, p. 118) both record the finding of specimens at a height of twenty feet from the ground in decayed trees.

Scaphiopus hammondii Baird. Western Spadefoot Toad.Previous records from British Columbia: Keremeos, Okanagan Landing, Penticton and Vernon.

All our specimens of this interesting toad were taken at Summerland where it was evidently common, for the larvae were abundant in ponds, ditches and puddles although the adults were rarely found.

The colour in life was grayish green above and more or less mottled; a longitudinal whitish stripe down each side of back from behind orbits to a little behind knees, and one along each side from behind ear; a short median whitish stripe on posterior part of back (over urostyle); a darkish blotch over orbit passing backward and inward, and a darkish line from eye to nostril; tubercles on back and sides tinged with orange; throat dusky, belly white.

On the evening of July 6,1928 , the toads began calling at twilight in some shallow ponds between the highway and the lake, just north of Summerland, and after dark we approached the ponds with flashlights and collected eleven specimens at the water. Two others were taken on the clay bluffs across the road from the ponds.

Mature and transforming tadpoles ranging up to $70 \mathrm{~mm}$. in length were found on July 2 , in a large pond south of Summerland, formed by the flooding of a pasture field. The water in this pond was much polluted with stock manure and of a cloudy, brown colour. Under cover about the margins we found multitudes of young toads with their tail trunks in various stages of absorption, many of which were still almost of full length. On the highway which passed close to the pond were the crushed bodies of hundreds of the little toads which had been killed by motor cars while they were migrating at night to the clay bluffs on the opposite side. High up on these bluffs, in a very dry place, we found one of the little toads still possessing a tail stub.

Cope (1889, pp. 307-308), describes the precocious behaviour of the larvae of Spea hammondii bombifrons (=Scaphiopus hammondii) at Market lake, Idaho, where on August 11, 1886, he found larval specimens which had climbed out of the water and were feeding on grasshoppers which had been washed up on the shore. He writes "Their limbs were nearly fully grown, while their tails had suffered no absorption, and their jaws were toothless and cartilaginous; some quite larval in form, others with wider gape. They were engaged in eating the grasshoppers, and I detected several specimens with the entire insects in their mouths."

On July 3,1928 , tadpoles were found in a shallow puddle on the side of the road opposite the busy fruit packing house at Summerland; the 
water of this puddle was churned into mud along the outer edge by the wheels of passing traffic. It seemed a most unsuitable place for tadpoles, yet they were evidently thriving; most of them ranged between 20 and $45 \mathrm{~mm}$. and some of them had attained a length of over $60 \mathrm{~mm}$. with their hind legs appearing.

Apparently any kind of temporary and even polluted puddle will serve this species for its brief larval period. The large pond in the flooded pasture field south of Summerland where transforming specimens were found on July 2 , had contained water for less than a month, according to Mr. Gartrell; this indicates rapid development from egg to transformation. Storer (1925, p. 159) shows that a similar rapid development occurs in S. holbrookii and S. couchii.

In transformation from tadpole to toad the body shows considerable reduction in size. Measurements of twenty-five mature tadpoles and of the same number of recently transformed toads show an average reduction in body length of $5.4 \mathrm{~mm}$., and the reduction in width would be proportionately even greater.

There are eight adult specimens in the Museum collection, one female and seven males, all of which were taken at Summerland on July 6,1928 . The preserved specimens measure from 40 to $59 \mathrm{~mm}$. in length, the average of all being $48.25 \mathrm{~mm}$. The female measures $51.5 \mathrm{~mm}$. and was full of eggs.

Bufo boreas boreas (Baird and Girard). Northwestern Toad.Previous records from British Columbia: Near Atlin, Bear lake, Bella Coola, Chilliwack lake, Clinton, Creston, Daisy lake near the head of Howe sound, Field, Fraser river, Garibaldi park, Glacier, Hatzic, Hazelton, Meadow lake twenty miles north of Clinton, Moose lake, head of Moose river, North fork of Moose river, Namu, Okanagan, Stikine river at Doch-da-on creek, Sumas prairies, four miles north of Telegraph creek, Vancouver, and Watson lake forty-five miles north of Clinton on the mainland; Alberni valley, Goldstream, and North Pacific Coal mines on Vancouver island; Gabriola island; Clew and Masset on Queen Charlotte islands.

In 1928 we found this species at Kaslo and Nelson, Six Mile lake near Nelson, Mirror lake near Nelson, Christina lake, Summerland, Brent's lake near Summerland, and at Nanaimo. We have some specimens from Lytton, and some from the Fraser valley collected by Miss A. P. McDougall in 1925, but for which no exact locality is given.

In the Museum collection there is a total of forty-eight specimens from British Columbia, thirty-one males, seven females, seven very young specimens (not sexed), and three tadpoles. The largest male measures $102 \mathrm{~mm}$. and the largest female $108 \mathrm{~mm}$. in combined length of head and body. 
In living specimens the ground colour above may be yellow, green or brown; a light mid-dorsal streak from between eyes to posterior tip of body; warts brown, usually enclosed in black or dark brown blotches especially on anterior part of body; parotoid glands light brown, these and the warts often tinged with red; skin of back between dark blotches often closely marked with minute, irregular dark spots with pale margins; sides of body blotched or marbled with black; limbs barred or blotched with dark brown or black; the large parotoid-like wart on tibia light brown; under parts dull white, frequently blotched or spotted with black.

On the nights of June 11 and 12, 1928, these toads were seen in numbers in a large pond on the beach at Kaslo. The males were calling and greatly outnumbered the females; nearly all the specimens collected or examined at the pond were males. One male was seen on the beach in embrace with a dead female which was much dried and shrivelled. On the night of June 12 strings of eggs were found strewn about among the grasses in the pond in water six or eight inches deep. The water temperature was $66^{\circ} \mathrm{F}$. Three tadpoles were taken in Brent's lake on July 1,1928 , they measured 41,44 and $44 \mathrm{~mm}$. in length.

A female of $108 \mathrm{~mm}$. taken at Kaslo on June 11, 1928, had apparently finished spawning; two other specimens of 81 and $101 \mathrm{~mm}$. taken at Summerland in July, one on the 17th, were full of eggs. A specimen of $93 \mathrm{~mm}$. taken at Lytton between the 1st and 8th of July, 1925, had evidently spawned.

Patch (1922, p. 76) writes: "This species was particularly abundant at Bella Coola. July 10, $27 \mathrm{~mm}$. larval specimens were taken in a "flood puddle" at Bella Coola. Aug. 20, "thousands" of young specimens were observed, in some cases piled inches deep, on a muddy, log strewn flat."

Hyla regilla Baird and Girard. PACIFIC TREe-TOAD.-Previous records from British Columbia: Armstrong, Beak lake, Chilliwack lake, Hatzic, Kaslo, and Sumas prairies on the mainland; Comox lake, Esquimalt, Florence lake, Mount Tolmie, San Juan, Union bay, and Victoria on Vancouver island; Taylor bay on Gabriola island.

This species was taken in the Fraser valley in 1925 by Miss A. P. McDougall. In 1928 it was taken at Kaslo, Christina lake, Summerland, Penask lake, Paul lake, near Nanaimo, and on Newcastle island in Departure bay.

The colour in life is highly variable. In the specimens seen by the writer the ground colour above on head, body and limbs ranged from light yellowish green to moderately dark brown. A bright yellow stripe from snout to near insertion of arm, and above this a brown stripe narrow from nostril to eye, widening through eye and passing back to above arm, were always present. In the brownish colour phases there were elongate 
dark blotches on the back, of ten more or less paired on the body, and a single $T$-shaped blotch on the head with the arms extending over the orbits and the stem passing backward; limbs blotched or barred with brown above. Under parts white or pale yellow, or soiled with a faint purplish brown; throat dusky in males.

There are twenty-one frogs and twelve tadpoles in the Museum collection. Of the frogs eight are males, six are females and seven are young specimens not sexed.

A female of $42 \mathrm{~mm}$. taken at Summerland on July 3, 1928, by Mr. T. B. Kurata, had some large eggs in the ovaries but had evidently spawned some time before. Another specimen of $36.5 \mathrm{~mm}$. taken at Penask lake on July 16, 1928, by Mr. G. N. Gartrell, was full of eggs. A female of $40 \mathrm{~mm}$. taken in the Fraser valley between May 1st and 15th, 1925 by Miss McDougall, still contained some large eggs but had evidently spawned at least part of its complement. The remaining three females which measured $27 \mathrm{~mm}$. or less, contained no eggs which were visible on gross dissection.

The tadpoles were taken at Paul lake near Kamloops by Mr. C. M. Mottley on July 20, 1928. They ranged in length from 43 to $53 \mathrm{~mm}$., the average being $48.43 \mathrm{~mm}$. In one specimen the hind limb buds were minute, in six the hind limbs were large, and in five the fore limbs were also developed. The tails were still complete in all specimens.

Rana aurora aurora (Baird and Girard). OREGON RED-LEGged FroG.-Previous records from British Columbia: Hatzic, Vancouver, and Vedder crossing on the mainland; near Florence lake, and Port Renfrew on Vancouver island.

There are six specimens in the Museum collection, two males and four females. Five were taken near Nanaimo and one at Vancouver. The Vancouver specimen which measures $73 \mathrm{~mm}$. in length was taken by Mr. Kenneth Racey in April, 1929, and ripe eggs were escaping from the vent. The others are all rather small, ranging from 40 to $57 \mathrm{~mm}$.

The colour in life was pale to dark brown above, often tinged with yellowish or reddish; head, back and sides closely to sparsely spotted or mottled with black or dark brown; a dark line from snout to eye, continuing backward above ear; dorso-lateral folds often coppery; front limbs mottled or mottled and banded, hind limbs mottled and banded with dark brown; ventral surface yellowish-white with some dusky mottling, usually faint; hind limbs sometimes reddish beneath.

Rana pretiosa pretiosa (Baird and Girard). Western SpotTed Frog.-Previous records from British Columbia: Lake Bennett, Clinton, Daisy lake near head of Howe sound, Field, Hanceville, Hazelton, Kispoix valley north of Hazelton, Kootenay lake, Meadow lake twenty miles north of Clinton, Moose lake, North fork of Moose river, Okanagan, 
Penticton, Sicamous, Stikine river at Dach-da-on creek, Flood Glacier, Sawmill lake and Telegraph creek, Sumas prairies, and Watson lake forty-five miles north of Clinton.

The specimens from British Columbia in the Museum collection were taken at Six Mile lake and Cottonwood creek near Nelson, at Christina lake, at Summerland and Brent's lake near Summerland, and at Lytton.

The specimens seen by the writer showed the following coloration in life: ground colour above on head, body and limbs light yellowish brown to medium dark brown; body and head spotted above with black, the spots on the body often grouped together, either separate or more or less fused, forming irregular roundish patterns resembling ink splashes; hind limbs barred with brown and frequently spotted with black, front limbs spotted or blotched; under surfaces yellowish white, with or without mottling, often richly coloured with salmon on belly and limbs especially in large specimens.

Some large light yellowish brown specimens taken at Brent's lake were suffused all over the upper surface with a reddish hue most evident on the dorso-lateral folds.

The dark spotting of the back and sides is much reduced on some of the specimens at hand and practically absent from one, but the dark barring of the hind limbs is present on them all. There are thirty-four frogs of this species from British Columbia in the Museum collection, of which nine are males and twenty-five are females.

A female of $61 \mathrm{~mm}$. taken at Cottonwood creek on June 6, 1928, had rather large ovaries with enlarging eggs. Two females of 46 and $74 \mathrm{~mm}$. taken at Six Mile lake on June 19, two of 58 and $60 \mathrm{~mm}$. taken at Christina lake, June 26 to 28, 1928, and two of 62 and $63 \mathrm{~mm}$. taken at Lytton, July 1 to 8,1925 , had only minute eggs in their ovaries. Two females of 89 and $93 \mathrm{~mm}$. taken at Brent's lake on July 1, and four of from 73 to $78 \mathrm{~mm}$. taken at Summerland on July 6, 1928, contained ripening eggs. Another specimen of $51 \mathrm{~mm}$. taken at Summerland on July 20, 1928, had small ovaries with minute eggs. Dickerson (1906, p. 219) gives the month of March as the spawning season for this frog at Puget sound. The above limited data would suggest that in the interior country it occurs in June and July.

Nineteen tadpoles were taken in Brent's lake on July 1, 1928. They ranged in length from 43 to $76 \mathrm{~mm}$. In two of them, all four limbs were functioning; in two more the front limbs were well developed and could be seen folded beneath the skin; in seven others the hind limbs were from one quarter to half grown. According to Dickerson (loc. cit.) larval development is rather slow and though completed in the one season "it is not until the summer is past that the tadpole becomes 
a frog." Storer (1925, p. 274) records the capture of a young individual of $26.4 \mathrm{~mm}$. in length, and "hence of the season's brood" on September 19, 1923, at Warner creek, Shasta county, California (altitude, 6600 feet). There would seem to be little doubt that the mature and transforming tadpoles taken at Brent's lake on July 1, with an average body length for all of $21.98 \mathrm{~mm}$, and for the eleven larger specimens of $27.63 \mathrm{~mm}$., belonged to the brood of the preceding year and had wintered over as tadpoles, and consequently were ready to begin transformation earlier in the summer than those nearer the coast (Puget sound) which go through their metamorphosis in the same year in which they are hatched.

\section{Reptiles}

Gerrhonotus principis (Baird and Girard). Northern Alligator LIZARD.-Previous records from British Columbia: Creston, Kaslo, Lillooet River valley, Sicamous, and Vedder crossing on the mainland; Nanaimo, Mount Tolmie, Shawnigan, and Victoria on Vancouver island.

A total of eight specimens is in the Museum collection. Six were taken near Nanaimo, one at Harrison lake, and one at Okanagan Landing. Of these, four are females and three are males, while the remaining specimen, apparently a male, was so badly injured as to make sex determination doubtful.

A female taken by Major Allan Brooks at Okanagan Landing on July 1, 1926, and another taken near Nanaimo in July of the same year were pregnant. In a specimen taken near Nanaimo in August, 1928, the ovaries showed some enlarging eggs but the uteri were empty.

Four of these specimens had perfect tails and ranged in total length from 147 to $259 \mathrm{~mm}$. The average total length was $204 \mathrm{~mm}$. and the average tail length was $114.75 \mathrm{~mm}$. for these four.

A specimen was taken by Captain H. H. Creese at Tulip creek, Lower Arrow lake, on September 25, 1930, and at the time of writing is still alive at the Department of Biology, University of Toronto, and the sex and measurements are not known.

The specimens seen in life by the writer were olive-tinted gray above, paler and greenish below, and marked above with few to many dark brown spots.

Charina bottae (Blainville). Pacific Rubber SNake; Rubber BoA.-Previous records from British Columbia: Creston, Chilliwack prairies, Chilliwack river, Lillooet River valley, and Sumas prairies on the mainland; Vancouver island.

The specimens seen alive by the writer were olive brown above and pale yellow beneath.

This snake is apparently not rare in British Columbia. We secured 
one specimen at Summerland in 1928. In 1929 we received two more of these snakes, one taken by Professor G. J. Spencer at Vernon, and one by Major Allan Brooks at Okanagan Landing. In 1930 Mr. G. N. Gartrell took three more near Princeton and one at Keremeos and sent them to us. The specimen taken at Summerland was found by a resident sunning itself beside a creek in the early forenoon. It later regurgitated two young mice.

The specimens in the Museum are males; the scale counts and measurements are given below.

\begin{tabular}{|c|c|c|c|c|c|c|c|c|c|}
\hline 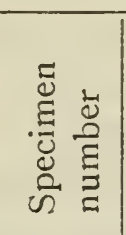 & 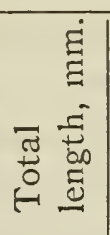 & 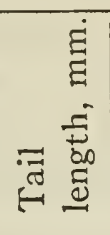 & 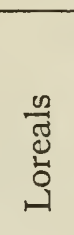 & 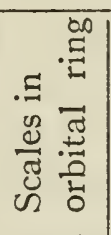 & 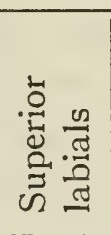 & 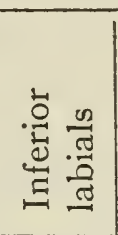 & 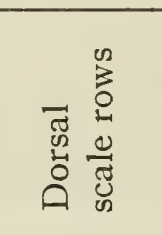 & $\begin{array}{l}\frac{n}{\pi} \\
\stackrel{5}{0} \\
0\end{array}$ & 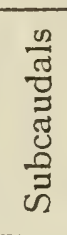 \\
\hline 2258 & 450 & 61 & $1-1$ & $8-7$ & $9-10$ & $11-11$ & $37-43-28$ & 206 & 36 \\
\hline 2581 & 493 & 66 & $2-2$ & $7-7$ & $10-10$ & $11-10$ & $39-43-29$ & 198 & 35 \\
\hline 2603 & 483 & 62 & $1-1$ & $6-7$ & $10-9$ & $12-11$ & $41-45-29$ & 206 & 37 \\
\hline
\end{tabular}

In the first and second specimen the fourth and fifth superior labial, respectively, on the left side enter the orbital ring, and are included in the above counts.

Coluber constrictor mormon (Baird and Girard). Western YELLOW-BELLIED RACER.-Previous records from British Columbia: Okanagan falls, and Vaseaux lake.

There are two specimens from British Columbia in the Museum collection. One was taken at Keremeos on July 11, 1928, by Mr. G. N. Gartrell and members of the Museum party. It was found early on a hot afternoon stretched out in a narrow band of shade cast by a piece of rock. The other specimen, a pregnant female, was taken by $\mathrm{Mr}$. Gartrell at Marron lake, southwest of Okanagan lake, on August 15, 1930, and was sent to us preserved.

The colour in life of the Keremeos specimen was grayish green above and pale yellow beneath, with a narrow blue band along each side on the lower half of the first scale row, and the edges of the ventrals. The colour of the Marron lake specimen, which is still fairly well preserved, was apparently similar.

The specimens are nos. 2257, male; and 2602, female. They show considerable variation, the measurements and scale counts are respectively: total length 686 and $788 \mathrm{~mm}$., tail length 191 and $182 \mathrm{~mm}$.; preoculars $2-2$; postoculars $2-2$ and $1-1$; superior labials $8-8$ and 7 -7; inferior labials $8-8$; dorsal scale rows $17-15$; ventrals 170 and 175 ; subcaudals 97 and 69 . 
Pituophis catenifer deserticola Stejneger. Desert Gopher SNake.-Previous records from British Columbia: Okanagan falls, Vaseaux lake and Vernon.

There are four specimens of this snake in the Museum collection: A female taken by Major Allan Brooks at Okanagan on July 26, 1926, and three males taken by members of the Museum party in 1928 at Green lake southwest of Okanagan lake on July 7, at Keremeos on July 11, and at Kaledon on July 20.

A specimen was taken at Vernon in 1929 by Professor G. J. Spencer and sent alive to the Department of Biology, University of Toronto.

The colour in life was pale straw-yellow above with dark brown keels to the scales; a series of forty-five to fifty-five brown dorsal blotches from head to above vent, pale at central and very dark toward anterior and posterior regions of body; twelve to sixteen blackish-brown cross bands on tail; belly yellowish white with brown or black spots, chiefly along the sides where the spots are spaced at intervals of two, three, or four plates. In two of the specimens at hand the spots are pale along the central region of the body, and faint and obscure ventrally. Head light brown above, mottled with darker brown or black on frontal and parietals; a dark transverse band across top of head just in front of eyes; a dark band from eye to angle of mouth, and a dark vertical spot beneath eye; labial sutures mostly marked with brown or black.

The oculars are $2+3$ on each side in all four cases; the varying characters are tabulated below.

\begin{tabular}{|c|c|c|c|c|c|c|c|c|c|c|}
\hline 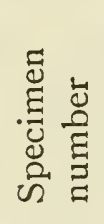 & $\stackrel{x}{\tilde{\omega}}$ & 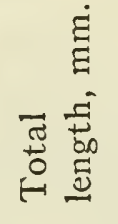 & 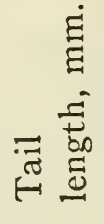 & 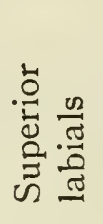 & 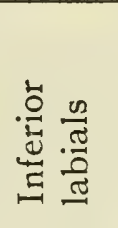 & 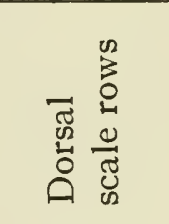 & 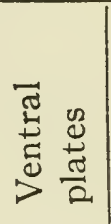 & $\begin{array}{l}\frac{0}{3} \\
\frac{\pi}{3} \\
\frac{\pi}{0} \\
\frac{0}{3} \\
n\end{array}$ & 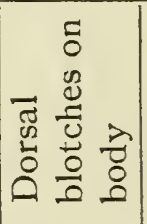 & 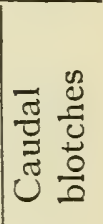 \\
\hline 2250 & $\mathrm{M}$ & 1210 & 170 & $8-7$ & $12-13$ & $29-31-22$ & 232 & 66 & 52 & 16 \\
\hline 2251 & M & 965 & 150 & $8-8$ & $13-13$ & $27-29-22$ & 231 & 64 & 55 & 15 \\
\hline 2252 & M & 890 & 132 & $8-8$ & $11-12$ & $26-30-21$ & 224 & 60 & 49 & 16 \\
\hline 2260 & $\mathrm{~F}$ & 338 & 50 & $8-8$ & $11-11$ & $27-31-21$ & 226 & 62 & 45 & 12 \\
\hline
\end{tabular}

The relation between the numbers of ventral plates and dorsal blotches, dorsal scale rows and preoculars, and caudal blotches and preoculars have been used by Van Denburgh (1922) and Blanchard (1925) to distinguish between the species of Pituophis. For the specimens described above these relationships are as follows: number of ventral plates less number of dorsal blotches on body and tail, 164, 161, 159, 169; number of scale rows plus number of preoculars on both sides of head, $35,33,34,35$; number of caudal blotches plus number of preoculars on both sides of head, $20,19,20,16$. 
Thamnophis sirtalis concinnus (Hallowell). NORTHWESTERN Garter-Snake.-Previous records from British Columbia: Bella Coola, Chilliwack prairies, Donald, Kaslo, Lillooet river valley, Lund, and Sumas prairies on the mainland; Alberni valley, Comox lake, and Union bay on Vancouver island; Gabriola island.

There are three specimens from British Columbia in the Museum collection. One was taken on Vancouver island in June, 1925, by Miss A. P. McDougall, but no exact locality is given; one at Ricter pass, between Keremeos and Osoyoos in July, 1928, by members of the Museum party; and one at Marron lake, between Penticton and Keremeos in August, 1930, by Mr. G. N. Gartrell.

The specimen from Ricter pass was black above, with yellow dorsal and lateral stripes; dorso-lateral spots of upper series fused, those of lower series separated by red blotches but fused with those of upper series; lateral stripe of each side bordered below by a dark band on first row of scales; ventral surface grayish-green, paler and more yellow anteriorly; a reddish spot covering last superior labial on each side.

In the three specimens at hand the dorsal stripe is wide, involving the central and half of each of the adjacent scale rows.

The scale counts are given below.

\begin{tabular}{|c|c|c|c|c|c|c|c|c|}
\hline 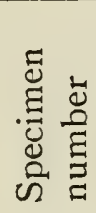 & 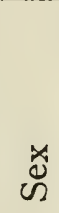 & 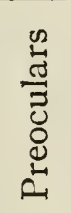 & $\begin{array}{l}n \\
0 \\
3 \\
3 \\
0 \\
0 \\
0 \\
0 \\
0\end{array}$ & 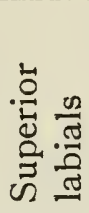 & 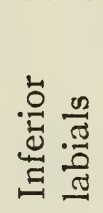 & 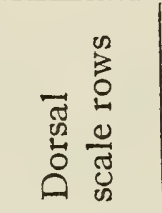 & 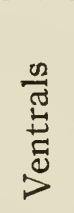 & $\begin{array}{l}\frac{\pi}{\pi} \\
\frac{\pi}{5} \\
\bar{J} \\
\frac{0}{7} \\
\text { n }\end{array}$ \\
\hline 1458 & $\mathrm{~F}$ & $1-1$ & $3-3$ & $7-7$ & $10-10$ & $19-18-17$ & 159 & 63 \\
\hline 1468 & $\mathrm{~F}$ & $1-1$ & $4-3$ & $7-7$ & $10-10$ & $19-19-17$ & 163 & 69 \\
\hline 2599 & M & $1-1$ & $3-3$ & $7-7$ & $10-10$ & $19-19-17$ & 166 & $72+$ \\
\hline
\end{tabular}

This form is very closely related to parietalis, from which it differs, according to Ruthven (1908, p. 173), only in the increased amount of black pigment and the attendant effect upon the pattern.

Mr. J. R. Slevin who identified our specimens informed the writer that as these snakes go northward concinnus reaches further to the eastward.

Thamnophis sirtalis parietalis (Say). Prairie Garter-Snake. Previous records from British Columbia: Donald, Hatzic, Kaslo, Nelson, Sicamous, and Vernon.

There are two specimens of this form from British Columbia in the Museum collection. One was taken in the Fraser valley in May, 1925, by Miss A. P. McDougall, and one at Princeton in September, 1930, by Mr. G. N. Gartrell. In the latter specimen, in which the colours seem to be fairly well preserved, the ground colour above is black, and the 
dorsal and lateral stripes are yellow; in both specimens the dorso-lateral spots of the upper series are fused, those of the lower series are separated from each other by red blotches but are more or less fused with the upper series; a red spot covers the last superior labial on each side; a dusky stripe along the first scale row; belly greenish yellow.

The specimens are nos. 1457, male; and 2600, female. The scale counts are respectively: preoculars $1-1$; postoculars $4-4$ and $3-3$; superior labials $8-8$ and $7-7$; inferior labials $10-10$; dorsal scale rows 19-19-17; ventrals 166 and 158; subcaudals 84 and 75 .

Thamnophis ordinoides ordinoides (Baird and Girard). Puget Garter-SNake.-Previous records from British Columbia: Atnarko, Lillooet River valley and Lund on the mainland; Baynes sound; Alberni valley, Comox lake, Gordon head, Nootka sound at Tahsis canal and Friendly cove, Rupert, Golden Eagle Mine on Mount Saunders, Union bay, and Victoria on Vancouver island.

This form is common on Vancouver island, where ten of the fifteen specimens in the Museum collection were taken; the other five were taken on the mainland. Of the Vancouver island specimens, four were taken in June, 1925 , by Miss A. P. McDougall, but no exact locality is given; two by Prof. J. R. Dymond in July, 1926, and two by the writer

\begin{tabular}{|c|c|c|c|c|c|c|c|c|}
\hline 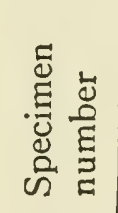 & 苑 & 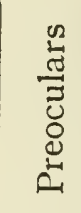 & 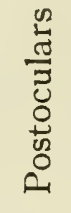 & 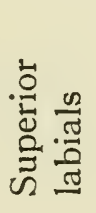 & 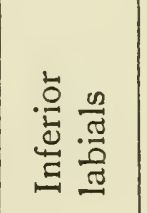 & 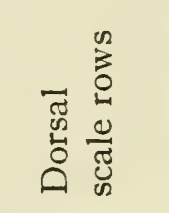 & 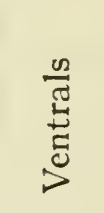 & 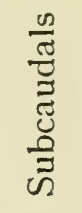 \\
\hline 1467 & $\mathrm{~F}$ & $2-2$ & $3-3$ & $7-7$ & $8-9$ & $17-17-15$ & 149 & 58 \\
\hline 1864 & $\mathrm{~F}$ & $2-2$ & $3-3$ & $7-7$ & $9-9$ & $17-17-15$ & 135 & 54 \\
\hline 1866 & $\mathrm{~F}$ & $2-2$ & $3-3$ & 7-7 & $10-10$ & $17-19-15$ & 146 & 57 \\
\hline 1867 & $\mathrm{~F}$ & $1-2$ & $3-3$ & $8-7$ & $9-9$ & $17-18-15$ & 148 & 54 \\
\hline 1868 & $\mathrm{~F}$ & $2-2$ & $3-3$ & $7-7$ & $8-8$ & $17-17-15$ & 142 & 55 \\
\hline 1871 & $\mathrm{~F}$ & $1-2$ & $3-3$ & $7-7$ & $9-9$ & $17-19-15$ & 145 & 57 \\
\hline 2243 & $\mathrm{~F}$ & $2-2$ & $3-3$ & $x-7$ & $x-9$ & $17-19-15$ & 151 & 63 \\
\hline 2245 & $\mathrm{~F}$ & $1-1$ & $3-3$ & $7-7$ & $9-9$ & $18-19-15$ & 145 & 49 \\
\hline 2248 & $F$ & $1-1$ & $3-3$ & $7-7$ & $10-9$ & $19-18-17$ & 141 & 56 \\
\hline 2282 & $\mathrm{~F}$ & $2-2$ & $3-3$ & $7-7$ & $9-9$ & $17-17-15$ & 141 & 56 \\
\hline \multirow[t]{2}{*}{2598} & \multirow[t]{2}{*}{ F } & \multirow[t]{2}{*}{$2-2$} & \multirow[t]{2}{*}{$3-3$} & \multirow[t]{2}{*}{ 7-7 } & $9-9$ & \multirow[t]{2}{*}{$17-17-15$} & 148 & 64 \\
\hline & & & & & Average & & 144.6 & 56.6 \\
\hline 1865 & M & $2-2$ & $3-3$ & $8-7$ & $8-8$ & $17-17-15$ & 143 & 63 \\
\hline 2246 & $\mathrm{M}$ & $1-1$ & $3-3$ & $7-7$ & $9-8$ & $17-17-15$ & 154 & 59 \\
\hline 2247 & M & $2-2$ & $3-3$ & $7-7$ & $9-8$ & $18-19-15$ & 137 & 61 \\
\hline \multirow[t]{2}{*}{2283} & \multirow[t]{2}{*}{ M } & \multirow[t]{2}{*}{$2-2$} & \multirow[t]{2}{*}{$3-3$} & \multirow[t]{2}{*}{$7-7$} & $9-9$ & \multirow[t]{2}{*}{$17-17-15$} & 146 & 63 \\
\hline & & & & & Average & & 145 & 61.5 \\
\hline
\end{tabular}


in August, 1928, near Nanaimo; one by Mr. H. W. Swaine at Victoria in June, 1929; and one for which there is no collector's name or exact locality. Of the mainland specimens, two were taken by Miss McDougall in the Fraser valley in 1925, but no exact locality is given; and three were taken by Mr. Kenneth Racey at Vancouver in May, 1929.

In the living specimens seen by the writer, the ground colour above ranged from brown or chestnut to olive, sometimes with a series of lateral spots; dorsal and lateral stripes brownish yellow, yellowish or greenish gray, in one specimen they were tinged with blue, in two others the dorsal stripe was tinged with red; a brown stripe on first row of scales; belly yellowish, olive, or gray.

The scale counts are tabulated on previous page.

Thamnophis ordinoides vagrans (Baird and Girard). WANDERING Garter-Snake.-Previous records from British Columbia: Victoria, Vancouver island.

The above record is by Fannin (1898), and appears to be the only one from British Columbia. The writer has questioned it, as vagrans was supposed to be an inland form reaching the western limit of its range in eastern Washington, eastern and central Oregon, and eastern California. But two specimens are at hand from the sea shore at Vancouver, so it seems not impossible that it may be found on Vancouver island also.

There are seven specimens of this form in the Museum collection. One was taken at Nicola lake in July, 1928, by Mr. G. N. Gartrell; two at Summerland in 1928 by the Museum party; two at Vancouver in 1929 by Mr. Kenneth Racey; one at Marron lake south of Okanagan lake, and one at Brent's lake near Summerland, in 1930 by Mr. Gartrell.

The specimens seen in life by the writer showed the following colora-

\begin{tabular}{|c|c|c|c|c|c|c|c|c|}
\hline 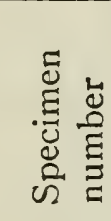 & 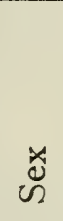 & 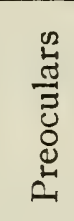 & 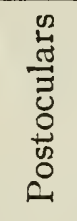 & 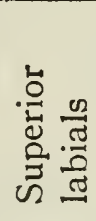 & 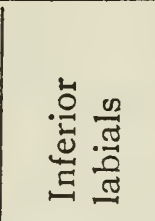 & 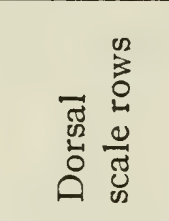 & $\frac{\frac{\pi}{5}}{\frac{\pi}{5}}$ & 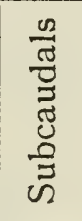 \\
\hline 1470 & $\mathrm{~F}$ & $1-1$ & $3-3$ & $8-8$ & $10-10$ & $21-21-17$ & 164 & $\mathrm{X}$ \\
\hline 2244 & $\mathrm{~F}$ & $1-1$ & $3-3$ & $8-8$ & $10-10$ & $20-21-17$ & 160 & 67 \\
\hline 2249 & $\mathrm{~F}$ & $2-1$ & $3-3$ & $8-8$ & $10-10$ & $21-21-17$ & 167 & 73 \\
\hline 2399 & $F$ & $1-1$ & $4-3$ & $8-8$ & $10-10$ & $20-21-17$ & 167 & 74 \\
\hline \multirow[t]{2}{*}{2601} & $\mathrm{~F}$ & $1-1$ & $3-3$ & $8-8$ & $10-10$ & $19-21-17$ & 158 & $\mathrm{X}$ \\
\hline & & & & & Average. & & 163.2 & 71.3 \\
\hline 1469 & M & $1-1$ & $3-3$ & $8-8$ & $10-10$ & $20-21-17$ & 174 & $\mathrm{X}$ \\
\hline \multirow[t]{2}{*}{2242} & M & $1-1$ & $3-3$ & $8-8$ & $10-10$ & $21-21-17$ & 168 & 87 \\
\hline & & & & & Average & & 171 & 87 \\
\hline
\end{tabular}


tion: ground colour above brown or olive brown; a light dorsal stripe of soiled yellow or pale brown, and a lateral stripe of the same or somewhat darker colour on the second and third scale row of each side; two series of alternating black spots along each side of dorso-lateral region, the upper series of which encroach on the dorsal stripe. In some specimens, toward the posterior half of the body, these spots become extended transversely into zigzag bands. A series of vertical black spots on bases of scales of first row. Under parts generally dusky; ventrals margined with black laterally on anterior edges, and marbled or heavily blotched with dark slate ventrally; top of head brown, heavily marked with black from eyes backward; pineal spot light; throat pale. In some specimens the light dorsal and lateral stripes are almost obsolete.

The scale counts for the above specimens are given on previous page.

It will be noticed that in the above seven specimens a preocular formula of $2-2$ does not occur, and of $2-1$ occurs once, or in approximately fourteen per cent. In a series of one hundred specimens examined by Van Denburgh and Slevin (1918, pp. 240-245) a preocular formula of $2-2$ occurs in thirteen per cent., and of $1-2$ in five per cent. ${ }^{2}$

Thamnophis ordinoides biscutatus (Cope). Klamath GarterSnake.-Previous records from British Columbia: Lillooet River valley on the mainland; Vancouver island.

There are three specimens in the Museum collection, all taken on Vancouver island; two by Miss A. P. McDougall in June, 1925, for which no exact locality is given, and one by Prof. J. R. Dymond near Nanaimo in July, 1926.

This form has not been seen in life by the writer. Van Denburgh (1922, vol. 2, p. 835) describes the coloration as "not different from that of typical Thamnophis ordinoides vagrans except that the dorsolateral regions usually are much darker. Because of this, the spots are less evident, but they may usually be made out." It is very close to vagrans. Blanchard $(1925, \mathrm{p} . \mathrm{x})$ did not consider it to be more than "a local emphasis upon a variation widespread in $T$. ordinoides vagrans and T. ordinoides ordinoides".

Van Denburgh and Slevin (1918, pp. 245-251) recognize this form and present a study of it based on two hundred and fifty-two specimens. A preocular formula of $2-2$ occurs in sixty-three per cent. of the specimens, and a maximum of twenty-three dorsal scale rows in approximately three and a half per cent. In one hundred specimens of vagrans (loc. cit. pp. 240-245) studied, a preocular formula of $2-2$ occurs in only thirteen

${ }^{2}$ In the preocular formulae given by Van Denburgh and Slevin the figure written first does not necessarily refer to the left side. 
per cent., the normal being $1-1$, and the maximum number of dorsal scale rows noted was twenty-one.

The specimens in the Museum collection show the following scale counts.

\begin{tabular}{|c|c|c|c|c|c|c|c|c|}
\hline 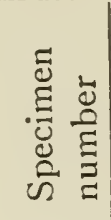 & 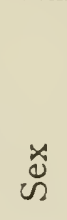 & 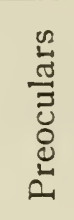 & 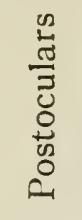 & 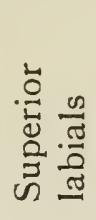 & 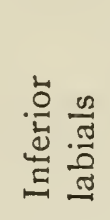 & 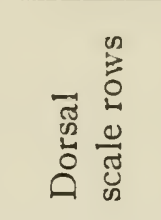 & $\underbrace{\frac{n}{\sqrt[N]{5}}}$ & 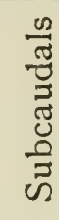 \\
\hline 1869 & M & $1-2$ & $3-3$ & $8-8$ & $10-10$ & $20-21-17$ & 163 & 75 \\
\hline 1870 & $\mathrm{~F}$ & $2-1$ & $3-3$ & $8-8$ & $10-10$ & $21-21-17$ & 161 & 61 \\
\hline 2287 & $\mathrm{~F}$ & $2-2$ & $3-3$ & $7-8$ & $10-10$ & $19-21-17$ & 165 & 74 \\
\hline
\end{tabular}

Thamnophis ordinoides elegans (Baird and Girard). MountaIN Garter-Snake.-Previous records from British Columbia: Bear lake, Nelson, Rocky Mountain park, Sicamous, and Vernon.

The above records are from Ruthven (1908, p. 140), and it should be mentioned that under elegans he included also the forms vagrans and biscutatus which have since been recognized as valid by Van Denburgh Slevin (1918), and are listed by Stejneger and Barbour (1923, pp. 114, 115).

The specimen from British Columbia in our collection was examined by Dr. A. G. Ruthven and by Mr. J. R. Slevin, both of whom pronounced it elegans.

This form has not been seen in life by the writer. The specimen at hand is a female, and was taken by Miss A. P. McDougall at Lytton in July, 1925. The stripes are obscure; there are two series of alternating dark spots along each side of the back, the upper series of which encroaches deeply on the dorsal stripe, the spots being coalescent across it anteriorly.

The scale counts are as follows: preoculars $1-1$, postoculars $3-3$, superior labials $8-8$, inferior labials $10-10$, dorsal scale rows $21-21-17$, ventrals 167 , subcaudals 68 .

Crotalus oreganus Holbrook. Pacific Rattlesnake.-Previous records from British Columbia: Ashcroft, Cache creek, Okanagan falls, and Vaseaux lake.

There are six specimens from British Columbia in the Museum collection, and five others still living at the Department of Biology, University of Toronto. These were collected at the following localities: one at Fairview by Miss A. P. McDougall; one at Keremeos by the Museum party; three at Marron lake southwest of Okanagan lake by Mr. G. N. Gartrell; three near Summerland by local residents; one at 
Vaseaux lake and one at Westbank by the Museum party; and one at Vernon by Professor G. J. Spencer.

In the specimens seen by the writer the ground colour was brown to grayish olive; dorsal blotches brown or greenish brown with darker margins, and becoming very dark on posterior part of body and on tail ; ventral surface yellowish white, more or less marked with brownish, especially on anterior edges of ventrals; a wide dark band from eye to angle of mouth, margined above by a narrow light line which is nearly obsolete in some specimens; top of head dark.

The measurements and counts of scales and blotches for the six specimens in the Museum collection are given below.

\begin{tabular}{|c|c|c|c|c|c|c|c|c|c|c|}
\hline 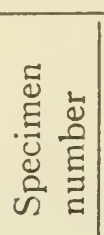 & $\stackrel{x}{\ddot{u}}$ & 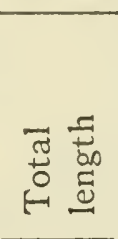 & 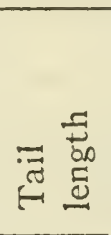 & 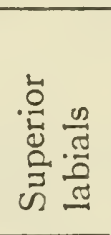 & 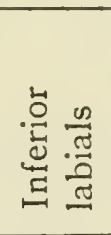 & 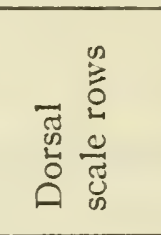 & $\stackrel{\frac{0}{E}}{\stackrel{\Xi}{5}}$ & 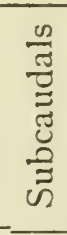 & 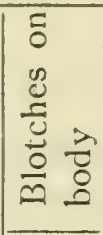 & 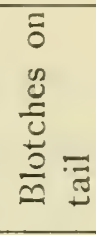 \\
\hline 2203 & M & 1018 & 6 & $17-15$ & $15-15$ & 23-26-19 & 171 & 23 & 34 & 4 \\
\hline 2204 & M & 90 & $5 !$ & $15-16$ & $14-13$ & $25-25-19$ & 172 & 22 & 34 & 4 \\
\hline 2205 & M & 842 & 60 & $15-15$ & 14 & $24-2$ & 169 & 23 & 32 & 4 \\
\hline 2604 & M & 868 & 59 & $15-15$ & 16 & $26-$ & 176 & 23 & 33 & 5 \\
\hline 1806 & $\mathrm{~F}$ & 284 & 16 & $14-15$ & $16-16$ & $24-25-20$ & 180 & 21 & 31 & 4 \\
\hline 2259 & $\mathrm{~F}$ & 462 & 24 & $14-15$ & $15-17$ & $24-26-20$ & 177 & 18 & 33 & 3 \\
\hline
\end{tabular}

On the 10 th of July, 1928, the writer in company with Mr. G. N. Gartrell, Captain H. H. Creese, and Mr. T. B. Kurata made a trip to Keremeos and Osoyoos lake where these snakes were reported to be plentiful. The weather was exceedingly hot. We arrived at Keremeos about noon and went first to a "rattlesnake den" on a bluff three or four hundred feet up on the side of a mountain, about seven miles west of the town. The snakes had deserted the "den" and all that we found were the remains of sheddings and excrement under the shelter of some rocks which we overturned, and Dermestes larvae feeding there. We searched the slopes and the bottom of the valley for hours, but without success. On July 11 we continued our search all day. The heat was intense; not until evening did we find our first specimen, which was lying curled in the shade of some tall sweet clover plants and under a tuft of sage brush close to an irrigation ditch-the coolest place it could find. In colour it was almost grass-green, and had it not rattled we would have passed it by.

On July 12 we went on to Osoyoos lake where we were met by, and had the kind assistance of Mr. R. M. Robinson, the game warden and Mr. C. Shuttleworth, Deputy Game Warden, both of whom knew this country exceedingly well. They took us to a "rattlesnake den" high 
up on the cliffs beside the lake, but the snakes had all gone. We continued our search of these rugged hills until evening but without success.

Mr. Gartrell informed the writer that in his experience these snakes avoided the intense heat, hiding away in sheltered places during the hottest days when they are more likely to be seen in the morning or late afternoon.

After the weather became a little cooler we found several specimens which had been killed on the roads.

This apparent aversion to intense heat is evidently not characteristic of the species throughout its range, because Van Denburgh (1922, p. 939) quotes from Dr. and Mrs. Grinnell as follows: "Many of these (Pacific rattlesnakes) were encountered on trails or open stretches of sand, where they had crawled in the hottest hours of the day." This was in the San Bernardino Mountains, in 1906.

The following is quoted from the above source: "A rattlesnake, as a rule, is a very timid animal; only when suddenly surprised in a broad, open space, does it fail to retreat into the nearest hiding place, such as a brush patch or rock pile. Then it coils and begins to rattle warningly. Sometimes, when loggy from cold or a recent heavy meal, the snake fails to rattle; but if it hasn't energy enough to rattle neither has it energy enough to strike. The senior author has several times put his foot close by and even kicked aside rattlesnakes; in each case there was no warning rattle, and in no case did the snake strike, until perhaps subsequently stirred up on purpose."

It is indeed regrettable that the majority of people who have the courage to do so will kill this snake on sight. It feeds largely on mice and gophers and is of undoubted economic value in controlling the numbers of these animals. It is not an aggressive species and cases of bite in British Columbia are extremely rare. The writer learned of one such case in recent years (Rod and Gun, vol. 29, pp. 647-648). This was of a boy of eleven years of age, who, finding a large specimen on a cliff, took a short stick and attempted to strike it and was fatally bitten. Hutchison (1929, p. 47) gives a table of snake-bite reports in the United States for the year 1928, and out of six hundred and seven cases, twentyseven, or less than four and a half per cent. were known to be referable to this species. There were one hundred and forty-eight, or nearly twenty-four and a half per cent. of cases by snakes of unidentified species.

Chrysemys marginata bellii (Gray). Western Painted Turtle. Previous records from British Columbia: Elkhorn lake, whole of Okanagan valley to north end of Okanagan lake, Vaseaux lake.

This species was taken at Vaseaux lake in June, 1913, by E. M. Anderson, who recorded it under the name of Clemmys marmorata, and reported it as common on all the lakes (Anderson, 1914, p. G 19). 
Anderson's specimens were collected for the Provincial Museum of Natural History, Victoria. One of them was kindly loaned to the writer by Mr. W. A. Newcombe of that Museum, and proved upon examination to be Chrysemys marginata bellii.

There are seventeen specimens from British Columbia in the collection of the Royal Ontario Museum of Zoology, six males and eleven females. In size of carapace they range from $98 \times 80$ to $193 \times 153 \mathrm{~mm}$.

In colour and marking they are exceedingly variable. The carapace varies from brownish to olive green, sometimes with fine mottling of black; scutes margined anteriorly with yellow; costal scutes with a yellow central line, usually crescent-shaped and vertically placed but variable in position and shape, sometimes branched; marginals marked with yellow, red and black; plastron yellow with a large central blotch of dark marbling which sends extensions out along the sutures.

T. L. Thacker studied this species in the Okanagan valley and gave a good account of nest making and egg laying, and made some interesting comments on distribution (Thacker, 1924, pp. 164-167). The Elkhorn lake record is from this source. Thacker apparently had not seen specimens from that locality, but stated that he had "trustworthy information that they occur above Elkhorn lake at an elevation of over 3,500 feet" and learned from Mr. De B. Green that they "regularly clean out cooking pots set to soak in the water at Elkhorn lake." They were observed by Thacker wandering on the land on the 29th of April, and the first nest was found on the last day of May, 1922. The method of nest making is similar to that of marginata in the east. A flask-shaped hole is dug and the soil is moistened by the turtle, which prevents it falling back in to the hole before the excavation is finished. The number of eggs laid is rather large as compared to marginata, as many as thirteen having been noted in a single complement. Apparently Bell's turtle is a little careless about properly covering the nest after the eggs have been laid.

On July 7, 1928, these turtles were seen in large numbers at Green lake, southwest of Okanagan lake, where they were sunning themselves in the very shallow water over a mud flat. Thirty-two specimens were brought back to the field laboratory for examination and all of them were Chrysemys marginata bellii.

This species was not seen to be positively identified at any other locality by the Museum party in 1928. Some turtles were seen by Mr. C. M. Mottley and the writer basking on logs at Christina lake, but they were very alert and it was not possible to get near enough to any of them to see the markings. 


\section{LITERATURE CITED}

Anderson, E. M. 1914-Mammals collected in the Okanagan valley, April, May, and June, 1913. Rep. Prov. Mus. Nat. Hist., Victoria, B.C., for 1913, pp. G 18-G 19.

Blanchard, F. N. 1925-A key to the snakes of the United States, Canada and Lower California. Pap. Mich. Acad. Sci., Arts and Let., 4, Part 2.

Cope, E. D. 1889-The batrachia of North America. Bull. U.S. Nat. Mus., 34. 1900-The crocodilians, lizards, and snakes of North America. Ann. Rep. U.S. Nat. Mus. for 1898.

Dickerson, M. C. 1906-The frog book.

Dunn, E. R. 1926-The status of Siredon gracilis (Baird). Copeia, no. 154 , pp. $135,136.1930$-Note on Ambystoma decorticatum. Copeia, 1930, no. 3 , pp. $87,88$.

Fannin, J. 1898-A preliminary catalogue of the collections of Natural History and Ethnology in the Provincial Museum, Victoria, B.C.

Hardy, G. A. 1926-Amphibia of British Columbia. Rep. Prov. Mus. Nat. Hist., Victoria, B.C., for 1925, pp. C 21-C $24 . \quad 1927$-Report on a collecting trip to Garibaldi park, B.C. Rep. Prov. Mus. Nat. Hist., Victoria, B.C., for 1926, pp. C 15-C 26. 1927-Amphibia of British Columbia. Additional notes and corrections. Rep. Prov. Mus. Nat. Hist., Victoria, B.C., for 1926, pp. C 37, C 38. 1928-Amphibia of British Columbia. Additional notes and corrections. Rep. Prov. Mus. Nat. Hist., Victoria, B.C., for 1927, p. E 17.

Hutchison, R. H. $\quad 1929$ - On the incidence of snake-bite poisoning in the United States and the results of the newer methods of treatment. Bull. Antivenin Inst. Am. 3:43-57.

Kermode, F. 1913-Accessions to the Provincial Museum during 1912. Rep. Prov. Mus. Nat. Hist., Victoria, B.C., for 1912, pp. Q 8-Q 10. 1927-Accessions. Rep. Prov. Mus. Nat. Hist., Victoria, B.C., for 1926, pp. C 38-C 40. 1929-Accessions. Rep. Prov. Mus. Nat. Hist., Victoria, B.C., for 1928, pp. F 23-F 25. 1930Accessions. Rep. Prov. Mus. Nat. Hist., Victoria, B.C., for 1929, pp. F 20-F 24.

Patch, C. L. 1922-Some amphibians and reptiles from British Columbia. Copeia, no. 111, pp. 74-79. 1929-Some amphibians of western North America. Can. Field-Nat., 43:137-138.

Ruthven, A. G. 1908-Variations and genetic relationships of the garter-snakes. Bull. U.S. Nat. Mus., no. 61.

Slater, J. R. 1930-Ambystoma decorticatum (Cope) rediscovered in Washington. Copeia, 1930, no. 3, p. 87. 
Slevin, R. 1928-The amphibians of western North America. Occ. เp. Cal. Acad. Sci., 16.

Stejnegar, L. and Barbour, T. 1923-A check list of North American a mphibians and reptiles.

Storer, 'T. I. 1925-A synopsis of the amphibia of California. Univ. Cal. Pub. Zool., 27.

Thacker, T. L. 1924-Notes on Bell's painted turtles (Chrysemys marginata bellii) in British Columbia. Can. Field-Nat., 38: 164-167.

Van Denburgh, J. 1922-The reptiles of western North America. Occ. Pap. Cal. Acad. Sci., 10: vol. 1, lizards; vol. 2, snakes and turtles.

Van Denburgh, J. and Slevin, J. R. 1918-The garter-snakes of western North America. Proc. Cal. Acad. Sci., Ser. 4, vol. 8, no. 6. 


8)

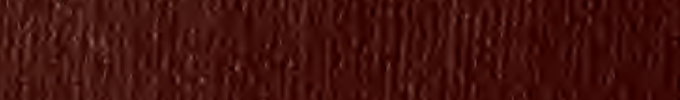

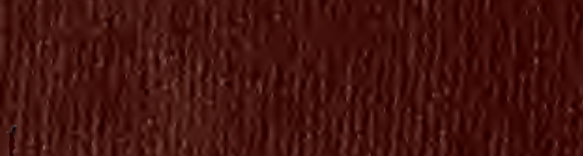

103 son.

s.

gevorom

4hos

36)

(s)

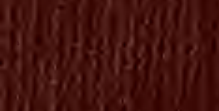

(ing

ing

sinth

(2)

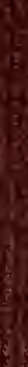

Bating

ing

ex: 